\title{
Perspectives
}

\section{Toward a Framework for Self-Regulated Language-Learning}

\section{Yoshiyuki Nakata}

English is a compulsory subject in many secondary EFL classrooms; thus the questions that arise for teachers are how to motivate learners in general and how to help them come to appreciate the value of English learning activities in particular. This article is based on the premise that learners benefit not only from becoming intrinsically motivated in what they do, but also when they feel responsible for, and autonomous in, their own learning. These processes involve the notion of self-regulated learning. The purpose of this article is to explore how intrinsic motivation and self-regulated learning relate to each other at a theoretical level and to suggest a three-stage framework for the encouragement of selfregulated learning. The author suggests that the Needs Analysis can be an apt means of inquiring into learners' previous language learning experiences and their preparedness for self-regulated language learning.

Le cours d'anglais étant obligatoire pour plusieurs élèves d'ALP, les enseignants sont aux prises avec les problèmes de motiver les apprenants en général et de les aider à apprécier la valeur des activités d'apprentissage en anglais en particulier. Cet article repose sur la prémisse que les apprenants tirent avantage non seulement de ressentir une motivation intrinsèque dans leur travail, mais également de sentir une responsabilité et une autonomie face à leur propre apprentissage. Ces processus impliquent le concept de l'apprentissage autoréglementé. L'objectif de cet article est d'explorer le rapport théorique entre la motivation intrinsèque et l'apprentissage autoréglementé et de proposer un cadre à trois étapes conçu pour stimuler l'apprentissage autoréglémenté. L'auteur propose qu'une analyse des besoins peut constituer un moyen efficace de se renseigner sur les expériences antérieures des élèves en apprentissage des langues et sur leur état de préparation en matière d'apprentissage langagier autoréglémenté.

\section{Introduction}

In the last 15 years, a growing literature has suggested that intrinsic motivation, autonomy, and self-regulation are interrelated (Dickinson, 1995; Dörnyei, 2001; Dörnyei \& Ushioda, 2009; Gao, 2007; Schunk \& Zimmerman, 2008; Spratt, Humphries, \& Chan, 2002; Ushioda, 2003; Wenden, 1998; Zimmermann, 2000). However, there appears to be no consensus among re- 
searchers as to how these factors are linked. This is not surprising, because such discrepancies among researchers to a greater or a lesser extent reflect differences of perspectives on affective, cognitive, and behavioral factors in learners' development. This discussion focuses on the process of developing intrinsic motivation and emphasizes the role that self-regulated learning plays in this process.

Motivation and self-regulation are two sides of the same coin. From a self-regulatory perspective, Bronson (2000) argues that self-regulation, "an intrinsically motivating activity in itself ... is required for successful engagement in a large number of activities" (p. 35). Zimmerman (2000) defines self-regulation as "self-generated thoughts, feelings, and actions that are planned and cyclically adapted to the attainment of personal goals" (p. 14). Recent discussions and empirical studies have tended to support the idea that the self-regulatory process is both cognitive and affective (Boekaerts, Pintrich, \& Zeidner, 2000; Schunk \& Zimmerman, 2008; Ushioda, 2003). However, viewed from the other side of the coin, motivational development, it also seems reasonable to think that motivation subsumes aspects of both affect and cognition. In other words, motivation encapsulates affective selfregulation (e.g., emotion and desire) and cognitive self-regulation (e.g., goalsetting, goal-directed reflection, and metacognition, Nakata, 2006).

It is highly likely that both intrinsic motivation and self-regulated learning entail the development of learner autonomy: a process that depends on "the learner's psychological relation to the process and content of learning" (Little, 1991, p. 4). The best-case scenario in this respect is for learners to enjoy what they do, to feel in control of their own learning (e.g., by setting their own goals), and to be able to take steps to manage or regulate the tasks they undertake to learn.

In this article, I first discuss the role that intrinsic motivation plays in successful language-learning and then suggest a pedagogical framework for teachers wishing to help learners not only to become more motivated, but also to become self-regulated in their learning. The basic premise is that intrinsic motivation when self-regulated not only affectively but also cognitively helps learners become autonomous language-learners, and as a result leads to successful language learning.

\section{Intrinsic Motivation Reconsidered}

Intrinsic motivation is the human need to be competent and self-determining in relation to one's environment (Deci \& Ryan, 1985). It has historically been considered positive and long-lasting, and so a large number of studies have been on intrinsic motivation not only in educational psychology (Deci \& Ryan), but also in language-learning (Noels, Pelletier, Clément, \& Vallerand, 2000; $\mathrm{Wu}, 2003)$. Apparently, many teachers of foreign languages, teacher 
educators, and researchers in TESL/TEFL or applied linguistics agree on the supreme importance of intrinsic motivation in language-learning. However, I wonder if intrinsic motivation studies in the literature-referring intrinsic motivation to interest or enjoyment-have entirely satisfied practitioners with respect to their pedagogical application. I have some doubts about the applicability of this theory to the classroom, where students are obliged to learn English as a compulsory subject no matter how much they like or dislike it. This is particularly true in EFL classrooms where there may be many constraints and limitations such as curriculum content, exam-oriented learning, large class size (commonly 35-40 students), and teacher-fronted instruction.

Brophy (2004) made the intriguing comment that intrinsic motivation is ideal but unattainable as an all-day, everyday motivational state for teachers to seek to develop in their students. As he pointed out, many intrinsic motivation theorists emphasize that learners' actions "must be experienced as self-determined if intrinsic motivation is to develop," which fails to address the distinction between its "affective/fun aspects" and its "cognitive/learning aspects" (p. 184). Viewed from the teacher's perspective, it is perhaps reasonable to note that motivational development is not simply a matter of intrinsic motivation in the framework of self-determination theory, and that neither is the development of intrinsic motivation simply a matter of degree (i.e., the continuum from external control to autonomous self-regulation, Deci \& Ryan, 1985). Intrinsic motivation must exist within the self, which refers to neither fun nor enjoyment (i.e., affective learning experience of play or recreational activities). In this respect, Brophy's idea of "motivation to learn" (p. 15)—the student's tendency to find learning "meaningful and worthwhile" and to seek "to get intended learning benefits" from academic activities, whether or not they find the content interesting or the processes enjoyable-is highly relevant. All these discussions lead me to infer that the notion of intrinsic motivation and its development must be discussed with regard to two agendas: the aspects of affect/fun and of cognition/learning.

We cannot ignore the realities and constraints of the educational context. At least insofar as the school context, especially the secondary school context, is concerned, intrinsic motivation must be compatible with achieving curricular goals.

Abundant evidence from the classroom suggests that intrinsic motivation is more than the concept put forward in self-determination theory. In fact I have seen many students who seemed to enjoy learning English, but were not necessarily successful in language-learning. Their intrinsic motivation was not long-lasting. In this respect, Nakata (2006) has reconceptualized intrinsic motivation by proposing a model-two levels of intrinsic motivationthat explains the developmental process underlying my view of intrinsic 


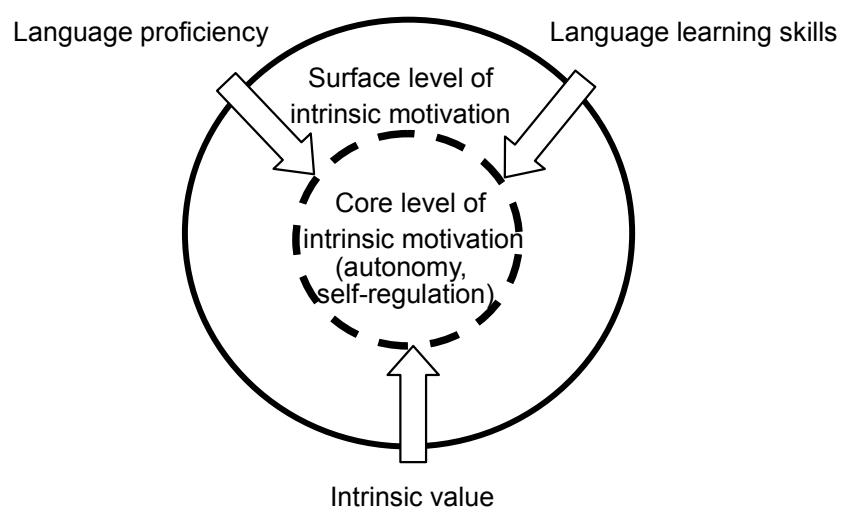

Figure 1. A developmental process model of intrinsic motivation: the prerequisite components (adapted from Nakata, 2006).

motivation. Figure 1 is a modified version of this model. With the core level of motivation, learners can manage their language-learning and consider learning in school or even at home as part of their lifelong language-learning, irrespective of teacher, teaching approach, or text material. This is the stage where learners are autonomous, self-regulated, and fully intrinsically motivated.

The surface level of intrinsic motivation is potentially developed first. At this level, learners study with enjoyment, but may cease studying in the future. They may have this level of motivation simply because they like the teacher or the teaching method. They could reach this level without fully achieving good language proficiency, mastering good language-learning skills, or internalizing the intrinsic value of learning a foreign language. This reflects the reality that whereas some learners possess a relatively high level of language proficiency and even achieve a certain level of language-learning strategies without successfully internalizing any intrinsic value in learning a foreign language (e.g., they find English enjoyable merely because of good test scores), other learners are willing to learn a foreign language simply because of an enthusiastic teacher or enjoyable tasks, but at the same time are not necessarily successful in internalizing its intrinsic value. At this stage, however, intrinsic motivation is still vulnerable to influences from external factors such as a teacher or a teaching method that the students dislike or poor test scores. This is the phase where learners' intrinsic motivation is not fully cognitively self-regulated, but rather simply affectively self-regulated. The teacher, therefore, needs to help them internalize the intrinsic value of learning a foreign language, while trying to provide them with at least some degree of autonomy and freedom even under constraints such as English as a compulsory subject, large classroom size, and teacher-fronted instruction. 
In my model, intrinsic value is to some extent conceptually linked to the notion of motivation to learn.

Essentially, in order to move on to the next level, learners need to acquire a level of language proficiency and language-learning skills and internalize the intrinsic value of language-learning.

\section{A Pedagogical Approach for Self-Regulated Language-Learning}

According to Zeidner, Boekaerts, and Pintrich (2000), self-regulation refers to the capacity to adjust one's actions and goals to achieve desired results in the light of changing environments. How, then, can we help pupils become self-regulated language-learners? Or how can we help learners move first to the surface level and then from the surface to the core level in the above model? Several steps are, of course, to be taken for self-regulated language learning to occur.

Bronson (2000) argued that although early self-regulation is primarily reactive, the child, "with maturation and experience ... (support and guidance from other people and from the mental and material tool kit)" provided by a particular cultural context becomes increasingly capable of "proactive, planful (well-planned), and conscious (metacognitive) control" (p. 2). Perhaps we can use her idea of self-regulation as the genesis for developing a context-sensitive pedagogical approach for self-regulated language-learning.

Ushioda (1996) went so far as to claim that the appropriate question about motivation no longer seems to be how we can motivate our learners, but how we help learners to motivate themselves. Elsewhere Ushioda (2003) reiterated her emphasis on the importance of intrinsic motivation, saying that motivation is a question not of the teacher finding strategies and incentives to get learners to do what they want, but of providing the right kinds of interpersonal support and stimulation so that learners will discover things they want to do for themselves. In the pedagogical approach outlined here, I argue that the appropriate question may not even be a matter of either/or, but rather of how best to combine these two tenets: that is, how we can motivate our learners and how we can help learners to motivate themselves, taking into consideration learners' language proficiency, language-learning skills, previous language-learning experiences, and all the constraints.

Table 1 sets out a pedagogical approach: Three stages of self-regulated language learning (preparation stage, developmental stage, and self-regulated stage). My discussion of Figure 1 may be recapitulated in relation to this table. For learners to move first to the surface and then from the surface to the core level of motivation, they need to acquire a certain level of language proficiency, language-learning skills, and a sense of intrinsic value; therefore, they need the teacher's guidance and encouragement. Ideally, teaching ap- 


\section{Preparation Stage}

1. Understanding learners' background via a Preliminary Needs Analysis

2. Creating a good classroom atmosphere

3. Establishing a trusting relationship between teacher and students

4. Improving learners' language proficiency by teaching them how to learn a foreign language to the level where they gain some degree of confidence in their ability to learn

5. Acting as a authoritative classroom manager

6. Providing learners with carefully selected freedom of choice

7. Focusing more on motivational self-regulation than cognitive self-regulation

8. Focusing on how to motivate learners directly under the constraints

9. Helping learners gain an interest in learning English

\section{Developmental Stage}

10. Evaluating the current state of learners via an On-going Needs Analysis

11. Focusing on how to help learners motivate themselves and to become more independent

12. Focusing more on cognitive self-regulation than motivational self-regulation

13. Providing learners with opportunities where they can taste the joy of self-expression and communicating in English

14. Setting the environment where learners can work collaboratively

15. Helping learners to set their own short- and long-term goals

16. (16) Helping learners to develop self-monitoring skills and reflection

17. Fostering mutual trust and support among learners

Self-regulated Stage

18. Acting as a facilitator of learners' language learning or as a language learning advisor

19. Maintaining learners' ability to take control of their own learning, regardless of teacher, teaching approach, or teaching materials

20. Providing learners with much less support

21. Providing learners with many opportunities for self-regulated learning

22. Providing learners with a wide variety of challenging and creative tasks in order to prevent them from becoming bored

proaches should be adopted on the basis of learners' needs (e.g., using a Needs Analysis). In order for self-regulation to happen in foreign-languagelearning, teachers must determine learners' level of preparedness for selfregulated language-learning. That is, teachers need to be aware of their learners' background: such elements as their language-learning history, their language proficiency, preferred learning styles and strategies, and attitudes toward language-learning, the factors impeding their progress and motivation, and the gap between their background and the teacher's own background as a language-learner and a language teacher (e.g., teachers' beliefs, teaching styles). On this basis, the teacher may perhaps modify his or her 
original lessons and syllabus. Beyond this, there must be a trusting relationship between teacher and learners, because motivation is dependent first and foremost on this relationship. This is especially true when teachers try to introduce learners to new teaching practices, because learners often express skeptical feelings and attitudes toward them.

Critical to what follows is that when we find learners lacking in motivation, we need to help them find some meaning in learning a foreign language (even if the reason for learning English is that it is a mandatory part of the school curriculum) and to guide them to set their own goals, both short-term and long-term. Perhaps the type of motivation needed here is the motivation to learn, which differs from enjoyment-driven intrinsic motivation. Otherwise, such learners, whose intrinsic motivation is solely affectively self-regulated, may not be successful in language-learning. At this stage, teachers may be focusing on how to motivate learners (Dörnyei \& Csizér, 1998) directly, even under existing constraints rather than how to help them motivate themselves (Ushioda, 1996, 2003, see Table 1). Teachers, therefore, need to make every effort to help learners improve their language proficiency, acquire their own language-learning skills, and find the intrinsic value of language learning (see the preparation stage in Table 1 ).

Given all the constraints and limitations typical of the educational context as suggested above, unfortunately, many EFL learners-and perhaps many EFL teachers-in secondary schools are likely to fall into the preparation stage. It may, therefore, be prudent for teachers in such EFL contexts to adopt the preparation stage approach if either teachers or learners are not ready for the next stage.

For teachers, the transition from the preparation stage to the developmental stage is marked by a shift in the agenda from how to motivate learners to how to help them motivate themselves. During the developmental stage, teachers need to provide learners with interpersonal support, provide them with opportunities to taste the joy of self-expression and communication in English, offer them an environment where they can work collaboratively, help them set their own short- and long-term goals, and help them to develop self-monitoring skills and reflection. In fact there is compelling evidence in support of the effect of collaborative learning on the development of motivation (Dörnyei \& Murphey, 2003; Nakata, 2006; Ushioda, 2003) and of goal-setting (Brophy, 2004; Ushioda, 1996). Having experienced this approach to learning, learners are likely to be motivated both affectively and cognitively. In other words, their intrinsic motivation is likely to become self-regulated both affectively and cognitively. As I found earlier, only after learners have gone through this stage is it possible for some to move on to the next stage, the self-regulated stage. 
Needless to say, each learner is a unique individual; thus language development varies from one learner to another. In keeping with their understanding of each learner through a Needs Analysis, teachers inevitably face the necessity of changing their roles from authoritative classroom managers to facilitators of each learner's language-learning (or language-learning advisors). With this information teachers can have further opportunities not only to revise the original syllabus and develop a more viable teaching approach, but also to provide each learner with meaningful feedback (not always positive, but informational) and with appropriate supervision. Having received such feedback from teachers, learners may gradually and naturally start to monitor and evaluate their progress-not only their products such as test scores, but also their learning processes-and feel that their effort is paying off, which in turn may offer a sense of accomplishment. As a natural corollary of such learning experiences, learners come to take control of their own learning regardless of the teacher, the teaching approach, or the teaching material.

Overall, there is no fixed template for developing learners' autonomy. However, it is clear that promoting learners' autonomy cannot be achieved without preliminary and ongoing investigations into which practices designed to develop autonomy, including curriculum and syllabus design, will be most suitable for learners (and perhaps teachers) at each stage in a particular educational context. In deciding on a pedagogical approach and modifying it, it is essential for teachers to inquire into learners' needs continually.

\section{Conclusion}

Much of the research literature on learners' autonomy and intrinsic motivation tends to discuss an image of ideal autonomous learners who are intrinsically motivated. In this there is danger that we may see learners' development from the perspective of cognitive self-regulation only. Here one might incorrectly assume that to help learners become autonomous, all teachers need to do is to help them develop the capacity for reflection and metacognition. However, we should not overlook learners' previous learning experiences, their language proficiency, and the various constraints implicit in varied educational contexts. The developmental process of motivation in relation to learners' evolving autonomy is both complex and dynamic. Hence it is crucial that the study of motivation in specific contexts include such elements as the social context and learners' previous learning experiences. In addition, we should be aware that the teacher undoubtedly plays a crucial role in the development of learners' intrinsic motivation, first to the surface, and then from the surface to the core level. To this end it is essential for teachers to be well aware of the process of self-regulated lan- 
guage-learning. Also, teachers should be sensitive to the pedagogical approach they adopt in promoting learners' autonomy, taking learners' preparedness into consideration. All this is imperative in the pursuit of self-regulated language-learning.

\section{Acknowledgment}

This is a revised version of a plenary paper presented at the 3rd Independent Learning Association Conference held at Kanda University of International Studies, October 15, 2007. I thank the Editor, anonymous reviewers, and Jennifer Ridley for their invaluable advice on this article.

\section{The Author}

Yoshiyuki Nakata (PhD, Trinity College, Dublin) is an associate professor of English language education and in the Joint Graduate School in Science of School Education at Hyogo University of Teacher Education, Hyogo, Japan. His research interests include language-learning motivation and teacher/learner autonomy in the Japanese EFL context.

\section{References}

Boekaerts, M., Pintrich, P.R., \& Zeidner, M. (Eds.). (2000). Handbook of self-regulation. San Diego, CA: Academic Press.

Bronson, M.B. (2000). Self-regulation in early childhood: Nature and nurture. New York: Guilford Press.

Brophy, J. (2004). Motivating students to learn (2nd ed.). Mahwah, NJ: Erlbaum.

Deci, E.L., \& Ryan, E.M. (1985). Intrinsic motivation and self-determination in human behavior. New York: Plenum.

Dickinson, L. (1995). Autonomy and motivation: A literature review. System, 23, 165-174.

Dörnyei, Z. (2001). New themes and approaches in second language acquisition research. Annual Review of Applied Linguistics, 21, 43-59.

Dörnyei, Z., \& Csizér, K. (1998). Ten commandments for motivating language learners: Results of an empirical study. Language Teaching Research, 2, 203-229.

Dörnyei, Z., \& Murphey, T. (2003). Group dynamics in the language classroom. Cambridge, UK: Cambridge University Press.

Dörnyei, Z., \& Ushioda, E. (Eds.). (2009). Motivation, language identity and the L2 self. Bristol, UK: Multilingual Matters.

Gao, X. (2007). Has language learning strategy research come to an end? A response to Tseng et al. Applied Linguistics, 28, 615-620.

Little, D. (1991). Learner autonomy 1: Definitions, issues and problems. Dublin: Authentik.

Nakata, Y. (2006). Motivation and experience in foreign language learning. Oxford, UK: Peter Lang.

Noels, K.A., Pelletier, L.G., Clément, R., \& Vallerland, R.J. (2000). Why are you learning a second language? Motivational orientations and self-determination theory. Language Learning, 50(1), 57-85.

Schunk, D.H., \& Zimmerman, B.J. (Eds.). (2008). Motivation and self-regulated learning: Theory, research, and applications. New York: Erlbaum.

Spratt, M., Humphreys, G., \& Chan,V. (2002). Autonomy and motivation: Which comes first? Language Teaching Research, 6, 245-266.

Ushioda, E. (1996). Learner autonomy 5: The role of motivation. Dublin: Authentik.

Ushioda, E. (2003). Motivation as a socially mediated process. In D. Little, J. Ridley, \& E. Ushioda (Eds.), Learner autonomy in the foreign language classroom: Teacher, learner, curriculum and assessment (pp. 90-102). Dublin: Authentik Language Learning Resources. 
Wenden, A.L. (1998). Metacognitive knowledge and language learning. Applied Linguistics, 19, 515-537.

$\mathrm{Wu}, \mathrm{X}$. (2003). Intrinsic motivation and young language learners: The impact of the classroom environment. System, 31, 501-517.

Zeidner, M., Boekaerts, M., \& Pintrich, P.R. (2000). Self-regulation: Directions and challenges for future research. In M. Boekaerts., P.R. Pintrich, \& M. Zeidner (Eds.), Handbook of self-regulation (pp. 750-768). San Diego, CA: Academic Press.

Zimmerman, B.J. (2000). Attaining self-regulation: A social cognitive perspective. In M. Boekaerts, P.R. Pintrich, \& M. Zeidner (Eds.), Handbook of self-regulation (pp. 13-39). San Diego, CA: Academic Press. 